\title{
The strategy of informing and tactics of its realization in the polemical discourse of the print mass media
}

\author{
Alena Sazhyna ${ }^{1}$, Marina Levchenko ${ }^{2, *}$, Veronika Shabanova², and Nina Skitina $^{2}$ \\ ${ }^{1}$ Francisk Skorina Gomel State University, 246019, Sovetskaya str, 104, Gomel, Belarus \\ ${ }^{2}$ Moscow Region State University, 141014, Vera Voloshina str.24, Mytishi, Russia
}

\begin{abstract}
All areas of our life, including interaction between people is now under the influence of technological progress. Information becomes available through various means, including the Internet variants of the press publications. In this sense, the polemical discourse of the print media becomes very popular with participants of communication - both the addresser and the addressee who get the possibility to take part in solving different urgent problems which arise in the society. The specifics of this kind of communication requires careful analysis in order to clarify the mechanisms of achieving the main goal of the polemical discourse of the print mass media, as well as compare them on the material of two languages - English and Russian. Mechanisms of realizing the communicative strategy of informing which are represented by the communicative strategies and have specific features have not been studied yet as the polemical discourse of the print mass media in its complete form has appeared only recently, at the end of the 20th century. The developed methodology was tested on the material from the English-language newspaper "The Guardian" and the Russian-language newspaper "SB. Belarus Today". As a result, the authors have identified the set of communicative tactics which serve the realization of one of the main communicative strategies of the polemical discourse of the print mass media - the strategy of informing. Moreover, the comparative analysis of the data obtained on the material of two not related languages can be used at practical classes in linguistics to develop students' skills in article writing and modeling strategic situations.
\end{abstract}

\section{Introduction}

Being in the center of attention of representatives of many sciences for decades, verbal communication with its laws and regulations is still of interest, since technological progress, together with various socio-cultural factors, changes the set of linguistic means that are used by communication participants to achieve their respective goals. In this regard, it seems relevant to continue researching communicative strategies on the material of various types of discourses, which will reveal, as far as possible, the mechanisms involved

\footnotetext{
*Corresponding author: author@email.org
} 
in the implementation of the intentions of participants in verbal communication, as well as identify a set of linguistic means that the addresser and the addressee use to achieve their communicative goals.

In recent decades, the results of linguistic research have shown an increased interest in such units as the text and the discourse. Being "the central moment of human life in the language" and "representing a particle of the continuously moving stream of human experience" [1, p. 10], the discourse has been studied by scientists within the framework of various approaches: the communicative one, the structural-syntactic one, the semantic and the social-pragmatic ones, which interpret the discourse as "verbal communication (speech, use, language functioning)" [2, p. 9], dialogue, conversation, etc. [3, p. 89]; as a superphrasal unity, a complex syntactic whole, a paragraph [4, p. 170]; the content of the constituent propositions, including local and global coherence at the micro and macro levels [5, p. 18-34]; as a text "plunged" in a situation of communication, life [6, p. 136-137]. For our study, the social-pragmatic approach was chosen, which allows us to consider the discourse as "a speech action, the participants of which are certain types of linguistic personalities, acting on the basis of certain circumstances and conditions of communication" [7, p. 30], since the polemical discourse of the print media, we are investigating, is "a set of coherent written texts representing the statements of participants in a certain polemic situation, which has as its communicative purpose a search for a solution to an urgent problem" $[8, \mathrm{p} .6]$.

The problem article as a genre covers a wide range of economic, social, political problems, issues of science, technology, education, etc., and its pragmatic attitude is realized with the help of such private author's attitudes as attitudes to attract the reader's attention, emotional impact, assessment, creating and maintaining contact with the reader, attitudes towards polemics, towards creating the impression of objectivity, attitudes towards motivation to action $[9$, p. 5$]$.

As previous studies show, the effectiveness of achieving a particular goal in the discourse is determined by competent planning, which is based on the choice of communication participants of a particular communicative strategy, the implementation of which is achieved through the use of a set of certain tactics. Tactics, in their turn, receive different linguistic representation on the material of different languages, which makes the ongoing research relevant from the point of view of comparative linguistics, since the material is analyzed on the example of the English and Russian languages, which are not closely related. Accordingly, the identification of the optimal linguistic resources involved in the communication process and serving to achieve the goal of the discourse under study can contribute to the description of strategically relevant situations and the potential set of tactics that are most acceptable to achieve the planned result, taking into account the variation in the communicative parameters of the discourse situation.

The research we are doing also seems relevant due to the fact that the subject is such a communicative discourse category as the strategic nature of the discourse, which is realized in the genres of a problem article and responses to it in the British English-language and Belarusian Russian-language press. We believe that the analysis of this category can help to find out the specifics of the linguistic representation of the main participants in polemical communication in the press in the contrastive aspect.

Turning to the consideration of the strategic nature of the polemical discourse of the print media, it is necessary, first of all, to define this category. For example, T. van Dijk interprets the strategy as a kind of general instruction for each specific situation of interpretation [10, p. 274]. According to M.L. Makarov, the speech strategy (in a broad sense) is a line (or a type) of the communicant's behavior in a specific communication situation, conditioned by the desire to achieve predominantly global (sometimes a number of local) communicative goals [11, p. 137-138]. O.S. Issers, in turn, defines the strategy as 
a certain sequence of actions (in this case - speech ones), organized depending on the goal of interaction [12, p. 111]. In this article, we understand the strategy as a communicative category, which is a process of planning and phased implementation by the author of an article of linguistic ways of correcting the model of the world of the addressee. Each strategy is realized by a set of specific tactics. Tactics, in turn, are a system of actions to prepare the effective implementation of strategies. Unlike the strategy, which lies outside of speech activity, the tactic deals with linguistic goals and describes actions at some stage of communication. Each tactic is used to change certain parameters of the addressee's world model and his knowledge, assessments, desires [13]. Being a complex of speech techniques for constructing a text, tactics, in contrast to strategies, can be identified by analyzing the text, since each tactic is actualized with a certain set of linguistic means.

The practical analysis of the polemical discourse of the print mass media made it possible to find out that it is characterized by the use of the strategy of informing, which is aimed at exchanging information between the author and the recipient.

Despite the rather wide coverage of communicative strategies and tactics of their realization in discourses of various types, the description of a set of tactics of the strategy of informing and language means of their realization in the polemic discourse of the print mass media in English and Russian remains unexplored, which makes our research relevant within the scope of the comparative analysis and with a view to reveal in full the nature of the discourse we study.

\section{Methods}

To solve all these problems, we propose to use several methods: the communicativepragmatic method, the comparative analysis method, the statistical method for processing empirical data. The practical analysis was carried out on the basis of problem articles from the English-language newspaper "The Guardian" and the Russian-language newspaper "SB. Belarus Today", selected by the continuous sampling method. Thus, the use of the communicative-pragmatic method contributed to the study of the features of the strategy of informing and the tactics of its realization in the process of communication in the polemical discourse of the print mass media. A set of tactics which are used in the realization of the communicative strategy of informing in both languages has been identified that mark the achievement of the main goal of the polemical discourse of the print mass media.

Table 1. Tactics of realization of the communicative strategy of informing.

\begin{tabular}{|c|c|c|c|}
\hline 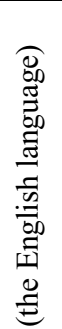 & . & $\begin{array}{l}\text { The compositional } \\
\text { division of the text }\end{array}$ & $\begin{array}{l}\text { Headline: In the coronavirus jobs wipeout, the } \\
\text { young and low earners suffer most. } \\
\text { Lead: Economic hardship is blighting some more } \\
\text { quickly than others. } \\
\text { Headline: With Keir Starmer in charge of Labour, } \\
\text { the Tories can be held to account again. } \\
\text { Lead: Expect the government's incompetent } \\
\text { handling of the coronavirus crisis to finally come } \\
\text { under proper scrutiny. }\end{array}$ \\
\hline 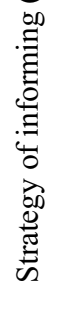 & $\stackrel{\mathscr{8}}{\oplus}$ & $\begin{array}{c}\text { The review and } \\
\text { analysis of facts, } \\
\text { publications, } \\
\text { statements of the } \\
\text { author or characters, } \\
\text { etc. }\end{array}$ & $\begin{array}{l}\text { - Not since Tony Blair in } 1994 \text { has a Labour } \\
\text { leader emerged from the party's byzantine } \\
\text { structures with support from every section, backed } \\
\text { by a majority of MPs, trade unions, affiliates and } \\
\text { now its members, too. He has promised unity and } \\
\text { this solid support may augur an end to the party's } \\
\text { civil wars. The respectful tone of the leadership } \\
\text { campaign in the three finalists' hustings drew } \\
\text { praise from all sides: peace was possible. }\end{array}$ \\
\hline
\end{tabular}




\begin{tabular}{|c|c|c|c|}
\hline & & & $\begin{array}{l}\text { - On Sunday, when he announces his new shadow } \\
\text { cabinet, it will stand in stark contrast to Boris } \\
\text { Johnson's team. An ill-assorted cabinet, chosen } \\
\text { for hot Brexit passions not character or } \\
\text { competence in a crisis, will face an impressively } \\
\text { capable line-up on the bench opposite. }\end{array}$ \\
\hline & & Quotations & $\begin{array}{l}\text { Direct quotation - On the evidence of the past few } \\
\text { months, Starmer may be too bloodless and } \\
\text { cautious a politician to pull this off. Maybe his } \\
\text { remainer convictions, and widespread mistrust of } \\
\text { his party, will deny him a big enough audience. } \\
\text { But in the speech released as his victory was } \\
\text { announced, there were at least hints of what the } \\
\text { moment requires: the elegant recognition that in } \\
\text { the midst of the crisis, "too many will have given } \\
\text { too much" and "some of us will have lost too } \\
\text { much"; the unanswerable claim that "we know, in } \\
\text { our hearts, [that] things are going to have to } \\
\text { change." } \\
\text { "So many volunteering for the NHS, millions of } \\
\text { people doing their bit to stop this virus and to } \\
\text { save lives," he said. "Our willingness to come } \\
\text { together like this as a nation has been lying } \\
\text { dormant for too long." } \\
\text { Indirect quotation - He conceded in his webinar } \\
\text { with members this week, "any government would } \\
\text { struggle", before pointing to confused messages, } \\
\text { slow action and the harsh light the crisis has } \\
\text { shone on a decade of austerity. }\end{array}$ \\
\hline & & $\begin{array}{l}\text { Repetition } \\
\text { lexemes }\end{array}$ & $\begin{array}{l}\text { This recession stands out for its scale and speed, } \\
\text { on both counts far outstripping the impact of the } \\
2008 \text { financial crisis that we thought would be the } \\
\text { defining economic event of our lifetimes. And this } \\
\text { is a jobs recession. Jobless numbers never grew as } \\
\text { expected during the financial crisis, but are } \\
\text { certainly picking up now. Last week, worries } \\
\text { about the economic impact of coronavirus became } \\
\text { reality - almost one million claims have been } \\
\text { made for universal credit in the past fortnight. Job } \\
\text { losses are spreading much faster than the virus. }\end{array}$ \\
\hline \multirow[t]{3}{*}{$\begin{array}{l}\text { Strategy } \\
\text { of } \\
\text { informing } \\
\text { (the } \\
\text { Russian } \\
\text { language) }\end{array}$} & \multirow[b]{3}{*}{ 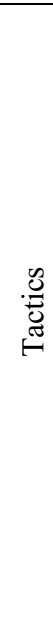 } & $\begin{array}{l}\text { The compositional } \\
\text { division of the text }\end{array}$ & $\begin{array}{l}\text { Headline: Should we be responsible for behavior } \\
\text { that can provoke crime? } \\
\text { Lead: Don't be a victim. } \\
\text { Headline: Don't give in to the crowd effect. } \\
\text { Lead: What does the flu have to do with it? }\end{array}$ \\
\hline & & \multirow{2}{*}{$\begin{array}{l}\text { The review and } \\
\text { analysis of facts, } \\
\text { publications, } \\
\text { statements of the } \\
\text { author or characters, } \\
\text { etc. }\end{array}$} & $\begin{array}{l}\text { - In the intestines of each person, about } 2 \mathrm{~kg} \text { of } \\
\text { different microorganisms live, there is even a }\end{array}$ \\
\hline & & & $\begin{array}{l}\text { tetanus bacillus. Among themselves, these } \\
\text { microbial "tribes" are in different relationships: } \\
\text { some are friends, with others they are at war. For } \\
\text { example, the flu virus and the coronavirus are at } \\
\text { war with each other, and the flu is naturally } \\
\text { stronger. Where there is a lot of flu, there is little } \\
\text { coronavirus. Without knowing this, medicine } \\
\text { since } 1996 \text { began to do large-scale flu } \\
\text { vaccinations. The bill went to millions of } \\
\text { vaccinated annually. As a result, Russia managed }\end{array}$ \\
\hline
\end{tabular}




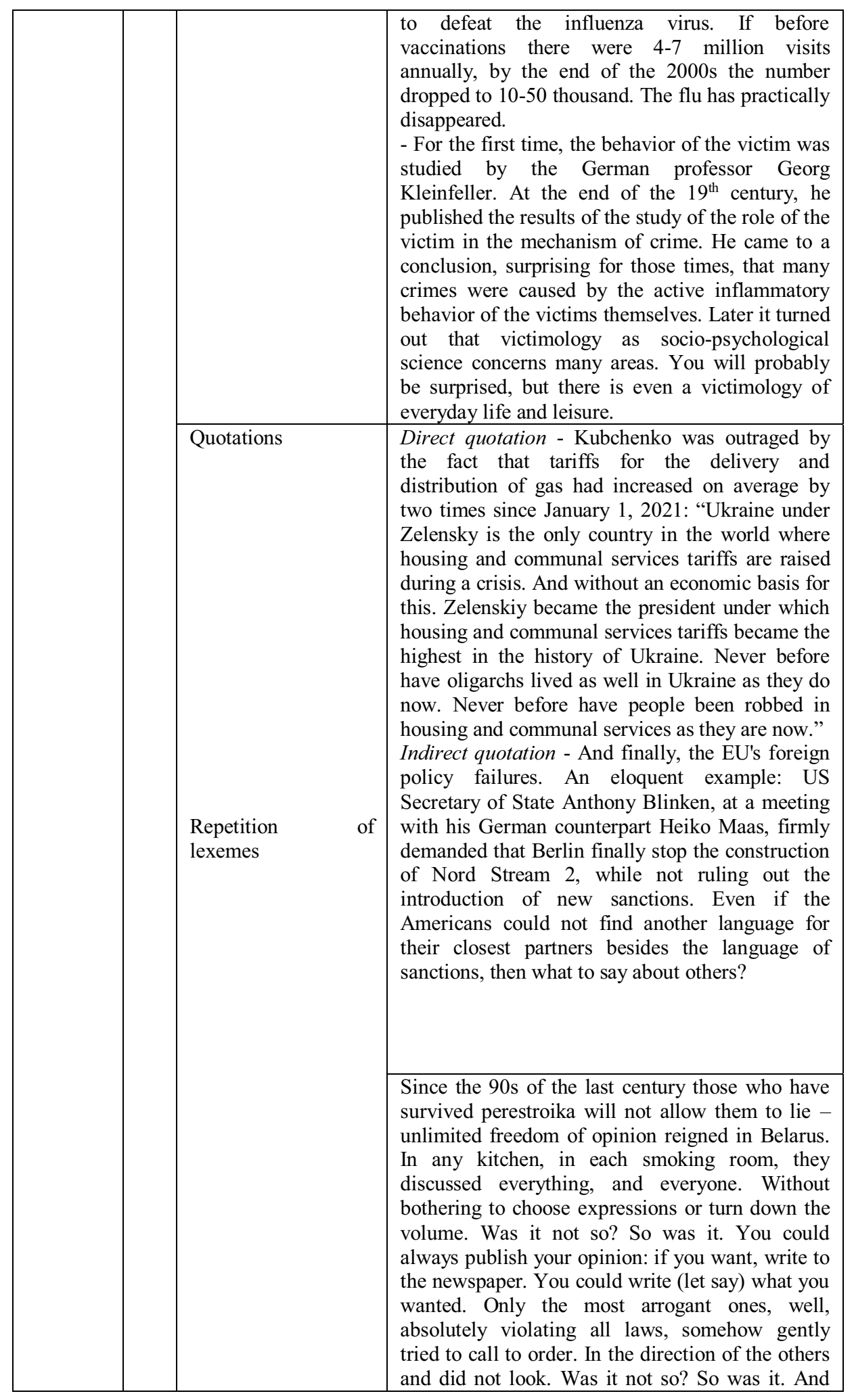




\begin{tabular}{|l|l|l|}
\hline & $\begin{array}{l}\text { the freedom of assembly was, let's say, endless. } \\
\text { To Bangalore. What freedom was missing in } \\
2020 ?\end{array}$ \\
\hline
\end{tabular}

Thanks to the use of the method of comparative analysis, it was possible to single out the specifics of the tactics of the review and analysis of facts, publications, statements of the author or characters, etc. in the polemical discourse of the print media on the material of two languages, which is expressed in the usage of hyperlinks in the English-language discourse and the absence of hyperlinks in the Russian-language one. The data were obtained due to the analysis of the problem articles.

Table 2. Special features of realization of the strategy of informing.

\begin{tabular}{|c|c|c|c|c|}
\hline & Hyperlink & Others \\
\hline \multirow{2}{*}{ 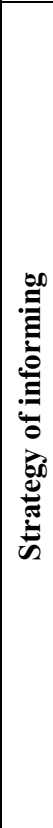 } & $\begin{array}{l}\text { The tactics of } \\
\text { the review and } \\
\text { analysis of } \\
\text { facts, } \\
\text { publications, } \\
\text { statements of } \\
\text { the author or } \\
\text { characters, etc.: } \\
\text { English- } \\
\text { language } \\
\text { problem articles }\end{array}$ & $\begin{array}{l}\text { Activists contended with the raw } \\
\text { incompetence of every aspect of the } \\
\text { Corbyn-led campaign, from his } \\
\text { incredible manifesto, ballooning } \\
\text { weekly with new billions pledged, } \\
\text { to basic failures to deliver election } \\
\text { leaflets on time. Many were } \\
\text { appalled to encounter voters, not } \\
\text { just in north London but in the } \\
\text { north of England, too, revolted by } \\
\text { the party's failure to root out } \\
\text { antisemitism. }\end{array}$ & + & - \\
\hline & $\begin{array}{l}\text { The tactics of } \\
\text { the review and } \\
\text { analysis of } \\
\text { facts, } \\
\text { publications, } \\
\text { statements of } \\
\text { the author or } \\
\text { characters, etc.: } \\
\text { Russian- } \\
\text { language } \\
\text { problem articles }\end{array}$ & - & - & - \\
\hline
\end{tabular}

The statistical method of processing empirical data, in turn, gave us the opportunity to find out the most widely used lexemes in the polemical discourse of the print media in two languages, which form the informative field of the discourse, thus realizing the strategy of informing most successfully.

Table 3. Repetition of lexemes.

\begin{tabular}{|c|c|}
\hline English-language problem articles & Russian-language problem articles \\
\hline+ & + \\
\hline $\begin{array}{l}\text { In short, we need good government by } \\
\text { politicians who believe in it and understand the } \\
\text { profundity of that responsibility. Good government } \\
\text { is not achieved by half-truths, dissimulation and } \\
\text { jokes. Johnson and his flyblown Brexity Tories are } \\
\text { demonstrating, as Britain's death rate begins to } \\
\text { exceed Italy's, that they are not the people for the } \\
\text { task. The question is not if, but when the government } \\
\text { accepts that its old faiths have died }-\langle\ldots>\text {. }\end{array}$ & $\begin{array}{l}\text { The curators suggested several } \\
\text { routes of the city "quest" for those who } \\
\text { have nothing to do at the weekend. } \\
<\ldots>\text { By the way, I would like to point } \\
\text { out separately that the services worked } \\
\text { very professionally and efficiently. } \\
\text { Many thanks to them! } \\
\text { So, initially there were two routes } \\
\text { for walking. }\end{array}$ \\
\hline
\end{tabular}


Table 3 presents the proof of the use of the tactics of repetition of lexemes in both languages in realizing of the strategy of informing in the polemical discourse of the print media. Further research will give an opportunity to identify the most widely-used repeated lexemes in the discourse which we study.

\section{Results}

The study has shown that an important role in the implementation of the strategy of informing in the polemical discourse of the print media is played by the tactics of the compositional division of the text, which provide the reader with unambiguous, objective and consistent information, since the most important information about the urgent problem is placed in the so-called strong positions of the text of the problem article - the title and the lead. However, as the practical analysis demonstrates, the discursive implementation of these tactics has its own similarities and differences in articles in English and Russian. So, in the English-language texts of problem articles information about a particular problem is already contained in the title itself and in the lead, which is the first paragraph of the text, whose main task is to interest the reader with information presented briefly in the lead itself, so that the reader can read it later in the article itself:

Headline: Trust is essential in these times. But Boris Johnson is not a man to be trusted.

Lead: Boris Johnson has shown a woeful lack of responsibility as the Covid-19 pandemic has escalated.

At the same time, the lead continues to reveal the essence of the problem, but in a short form. In the above example, the headline says that it is important to trust the government of the country at the moment, but there is no trust in Boris Johnson on the part of the British people, which is what the lead says.

In Russian-language problem articles in the Belarusian press, in turn, the compositional element "lead" is not a summary of the issue, but has a metaphorical character, adds color to the description of an existing problem or creates intrigue, as in the following example:

Headline: The film "Mankurt" (ONT) has filled up the incredible, as if a roaring bull was hit on the forehead with a butt.

Lead: We will name all traitors by name!

In this example, the intrigue is created when the author, in an exclamatory sentence, promises to reveal the essence of the headline in the article itself, thereby leaving the riddle and informing his readers that the names of the participants in the conspiracy will be revealed.

The next tactic that implements the communicative strategy is the review and analysis of facts, publications, statements of the author or characters, etc. on the problem discussed in the article. This tactic is characteristic of the polemical discourse of the print media in both languages, but in the English-language discourse it is also supported by technical capabilities in the form of hyperlinks, for example: The reality playing out before our eyes is that the NHS, for all the wonderful dedication of its staff, has an embedded lack of resilience. This is revealed by the chronic shortage of intensive care beds and the cancellation of all non-elective urgent surgery for at least the next three months. For decades, it was understood that hospitals should operate at $85 \%$ capacity to give them the margin to deal with crises, but for the last 10 years NHS (hyperlink) hospitals, under intense pressure from an austerity-driven Treasury to demonstrate their "efficiency", have been forced to operate at $95 \%$ capacity. The accent in the British hospital is on "throughput" and "maximum resource utilisation".

The reaction over the past few weeks has been great - the opening, on Friday of the first Nightingale hospital, in east London (hyperlink); the readiness of retired staff to accept recall; the response to the call for volunteers; the unflagging courage of NHS workers. But 
the health service started from a low base. Public health has been subordinate to the wider injunction: taxes must not rise because taxation is an encroachment on personal resource and liberty.

In the example we observe the implementation of this tactic by presenting the facts that took place earlier. At the same time, we are dealing with the case when there is an interaction of strategies of informing and persuasion, since the strategy of informing can also be achieved by the tactics of bringing the opinions of authoritative politicians, economists, etc. and is realized through direct or indirect quotation, as in the following examples:

The Guardian: No 10 did not want to offend the European Research Group, but this could not be honestly admitted. Thus, the unconvincing, and changing, answers to the issue of testing (invent a diagnostics industry in a month?) and to shortages of key medical equipment. Thus, the reaction to the disclosure that the British government had not participated in the EU scheme jointly to procure ventilators. This was obviously because No 10 did not want to offend the European Research Group, but this could not be honestly admitted. Emails had gone missing; there was administrative "confusion", claimed Michael Gove. All half-truths - perhaps worse; British officials had attended at least four EU meetings in which the joint buying of medical equipment was discussed.

The reality was ideological. There was nothing Britain could do jointly with the EU, Gove finally admitted, that it could not do as well as an independent country. That is not an attitude that signifies "whatever it takes", but puts, as critics have said, Brexit before breathing.

SB. Belarus Today: Vladimir Paniotto: "In general, the questionnaire looks quite professional, most of the questions do not cause any comments". Grigory Yudin: "At any normal sociological faculty, two points would be given for this work." Ivan Nizgoraev: "The questionnaire will be filled out only by an extremely motivated person or a person performing an assignment, whether he will be a respondent or an interviewer is not the point."

In the English-language newspaper, we see an example of indirect citation, which refers to words previously said by a British politician, a member of the Conservative Party, whom, according to the author of the article, the reader can trust. The Russian-language newspaper provides examples of direct citation of a Ukrainian sociologist, Doctor of Philosophy V. Paniotto, Doctor of Technical Sciences G. Yudin and Russian famous sociologist I. Nizgoraev, which also informs the reader about the reliability of the information provided.

An equally important role in the implementation of the strategy of informing belongs to the tactics of repetition of lexemes. Thus, the analysis of the problem article "Johnson seems unable to unify us. Who will speak for the country?" from the British newspaper "The Guardian" demonstrated that the most frequently repeated lexemes are as follows: 1) political (and its derivatives), 2) Tory (and its derivatives), 3) crisis / Corovirus, 4) conservative, 5) shift, 6) huge. Their repetitions in the text of the article mark the essence of the problem and allow the reader not to lose the thread of the events:

Last week, Boris Johnson stood on a set of stairs inside 10 Downing Street and spoke into a smartphone camera. Towards the end of a two-and-half minute monologue about Covid-19 <...>: "One thing I think [the] coronavirus crisis has already proved is that there really is such a thing as society." $<\ldots>$

Though Johnson may well have cited what she said to create a useful distraction among political journalists, what he said nonetheless highlighted something undeniable: that Conservative politicians used to following Thatcher's example are suddenly having to behave in ways that will be causing some of them no end of unease. 
In the spectacle of the chancellor Rishi Sunak's huge economic interventions and the government's sudden veneration of the public sector, you can discern Tory shibboleths being suddenly thrown overboard. But things are perhaps more complicated than they appear. Coronavirus will force shifts in policy of a scale no Tory politician would ever have foreseen, but they also chime with underrated things that have been present in postThatcher Conservatism for years. When David Cameron was in charge, there were periodic fits of interest in a more socially minded Toryism, $<\ldots>$.

Of course, austerity went on, inequalities were still ignored, and our exit from the EU quickly proved to be a huge distraction from the dire state of our social fabric. But in the midst of a sudden, unprecedented crisis, that is not quite the point. What matters right now is that much of the political groundwork has been done for Johnson and his allies to move away from free-market dogma, and in any case, they have no choice.

As and when we start to emerge from the coronavirus period, I would imagine $<\ldots>$, there are things lurking in this moment that play to the authoritarian part of the Tory soul, and they need to be closely watched. But make no mistake: a new political common sense will emerge from the crisis, and it will surely mark the start of a different era.

In the Russian-language problem article "Ukraine on the verge of a grand crisis" from the Belarusian newspaper "SB. Belarus Today" repeated lexemes are as follows: 1) Ukraine (and its derivatives), 2) housing and communal services, 3) problem, 4) tariff:

What this is fraught with, said the Ukrainian economist Boris Kushniruk: "The government is facing a terrible situation around the implementation of the state budget. The huge deficit will create huge problems, first of all, for the so-called unprotected expenses a certain part of them has already begun to be fulfilled, but there will be no funding for them. This is a classic problem that we already faced during the times of the governments of Tymoshenko and Azarov, <... . According to the head of the Housing Union of Ukraine, Oleksandr Skubchenko, expressed on the pages of Glavred, "Ukrainians have never been robbed like they were under Zelensky." Skubchenko was outraged by the fact of the increase in tariffs $<\ldots .>$ : "Under Zelensky, Ukraine is the only country in the world where housing and communal services rates are raised during a crisis. And without an economic basis for this. Zelenskiy became the president under which housing and communal services tariffs became the highest in the history of Ukraine. Never before have oligarchs lived in Ukraine as well as they do now. Never before have people been robbed in housing and communal services as they are now. "Europe today is clearly not up to Ukraine: here the "migrant issue" has become aggravated again. $<\ldots>$ Ukraine should return next year $<\ldots>$.

Thus, the tactic of repetition of lexemes makes it possible to create an information canvas of the polemical discourse of the print media in both English and Russian.

\section{Discussion}

To test the developed methodology of communicative strategy studies, the authors have investigated 50 articles from the English-language newspaper "The Guardian" with a total of 280 printed pages and the Russian-language newspaper "SB. Belarus Today" with a total of 278 printed pages. The proposed methodology for identifying the main tactics of realization of the strategy of informing in the polemical discourse of the print media in two languages can help identify the same tactics in the study of the Internet discourse, political, judicial, pedagogical and other types of discourse, as well as in further comparative studies of discourses in other languages. Further study of language means of tactics realization in the polemical discourse of the print mass media in two and more languages is seen as relevant.

The results can be used in courses of text linguistics, discourse analysis, theoretical grammar of the English and Russian languages, communicative grammar, practice of oral 
speech and in the courses "The Discourse of the Print Media", "Language of the Media" in higher educational institutions.

The tactics of realization of the strategy of informing, identified during the research, can be recommended for further use in developing students' skills in writing a problem newspaper article, as well as for strategic planning of situations within the framework of the discipline "Practice of oral and written speech of the English and Russian languages" on the topic "Mass Media".

\section{Conclusion}

Today's world cannot exist without the media, whose functions now are as follows: informing, influence, persuasion and, since the beginning of the $2000 \mathrm{~s}$ - participation. As a result, participants of the media communication have a possibility to discuss and take part in solving different problems, connected with economic, political, social spheres etc. In this communication process, the communicative strategies that are used by the addresser and the tactics of their realization are of interest to researchers in terms of studying the mechanisms of organizing the polemics between the addresser and the addressee in order to achieve the main goal of the polemical discourse of the print mass media - finding the solution to an urgent problem. Without effective tactics it is impossible to imagine successful communicative strategy realization. Therefore, the proposed methodology of research and the identification of communicative tactics that prove the successful implementation of the goal - informing - can become the basis for proving the strategic nature of the studied discourse and continuing research in the field of discourse analysis. The combination of the communicative-pragmatic method, the method of comparative analysis and the statistical method of processing empirical data provided evidence for the results and can form the basis for further research. Due to the identified sets of tactics on the basis of Englishlanguage and Russian-language polemic discourse of the print mass media it is possible to develop possible communicative models of the polemics, as well as to study the language means of realizing the tactics of the communicative strategy of informing in order to stimulate the response from the maximum number of addressees. The results obtained are also of interest for implementation in the educational process in higher education institutions as part of courses for students of linguistic specialties and future translators, as well as journalists. This study provides an opportunity to study the linguistic corpus of problem articles on the material of various languages in order to identify the most common linguistic units in the studied texts.

\section{References}

1. B.M. Gasparov, Language, Memory, Image: Linguistics of Language Existence (Moscow, 1996)

2. M. Stubbs, Discourse analysis: the sociolinguistic analysis of natural language (Oxford, Basil Blackwell, 1983)

3. D. Schiffrin, Discourse markers (Cambridge, Cambridge University Press, 1987)

4. V.A. Zvegintsev, Sentence and its relation to language and speech (Moscow, MSU, 1976)

5. T.A. van. Dijk, Dialogue and cognition, Cogn. C. on CRP, 18-34 (1984)

6. N.D. Arutyunova, Discourse, Linguistic Encyclopedic Dictionary (1990)

7. V.I. Karasik, The structure of institutional discourse, PSC, 25-33 (2000) 
8. A.V. Sazhyna, Structural and Pragmatic Characteristics of the Polemic Discourse (Minsk, MSLU, 2007)

9. A.E. Makaryavichyus, The problem article as a genre of an English newspaper (linguistic and stylistic aspect) (Moscow, M. Torez MSPIFL, 1989)

10. T.A. van. Dijk, Language. Cognition. Communication (Moscow, Progrss, 1989)

11. M.L. Makarov, Foundations of Discourse Theory (Moscow, Gnozis, 2003)

12. O.S. Issers, Communicative strategies and tactics of Russian speech (Moscow, LKI, 2008)

13. E.V. Lavrenko, Tactics of incentive strategies in information economic discourse, Annual Conference MSLU, 15-22 (2006) 